\title{
生体炎症のキーレギュレーター EPRAP
}

\section{藤川理沙子, 樋口 聖, 中辻 正人, 安井 美加, 横出 正之, 南 学}

\section{EPRAP とは}

EP4 receptor-associated protein（EPRAP）は，プロ スタグランジン $\mathrm{E}_{2}\left(\mathrm{PGE}_{2}\right)$ type 4 $(\mathrm{EP} 4)$ 受容体の新 規結合タンパク質としてマクロファージで単離された タンパク質であり (1), 線虫の性決定遺伝子 FEM-1の オルソログである Femla としても知られている．細 胞を用いた検討で, EPRAP がマクロファージの $\mathrm{PGE}_{2^{-}}$ EP4を介した抗炎症シグナルに重要であることや, EPRAPがマクロファージでEP4 受容体及び p105 と直 接結合し, p105のリン酸化と分解を抑制し, MEK-ERK の活性化を抑制することが明らかにされている(2). EPRAP がヒトの頸動脈アテロームに発現しているこ とも確認されており (1), 慢性炎症性疾患の治療夕一 ゲットとなる可能性が考えられた。

EPRAP は脳，肺，大腸など広く発現しているが，生 体における機能は不明であった，そこで我々は，生体 炎症におけるEPRAPの機能を明らかにするため, EPRAP 欠損マウス及び過剩発現マウスを作製し, 検討 を行った。

\section{EPRAP はマクロファージで炎症を抑制し 腸炎・肺炎を抑制する}

マクロファージの炎症応答が病態の発症や進行に 関わる慢性炎症疾患に着目し, 腸炎モデルと肺炎モデ ルを用いて EPRAP の機能を検討した。 まず，デキス トラン硫酸誘導性腸炎モデルマウスを用い, EPRAP 欠損により腸炎症が悪化することを明らかにした(3). また EPRAP 欠損マウスから骨髄移植した野生型マウ スで腸炎症が悪化したこと, cd68 下流に EPRAPを過 剩発現させたトランスジェニックマウスで腸炎症が改 善したことから，マクロファージの EPRAPが腸炎症 抑制に重要であることが考えられた，さらに EPRAP 欠損マウスでは EP4 受容体アゴニストの抗炎症作用
が示されなかったことから, EP4 を介したシグナルで EPRAPが重要な役割を担っていることが分かった. EP4 アゴニストは炎症抑制の他に $\mathrm{cAMP}$ 上昇を介した 下痢などの副作用があるが, EPRAP は cAMP 上昇に 関与しないため, より副作用の少ない治療ターゲット となる可能性がある.

次にブレオマイシン誘導性肺炎モデルを用いて, 腸 炎モデルと同様に EPRAP 欠損により肺炎症が悪化 することを明らかにした(4). EPRAP 欠損マウスでは 炎症刺激後にマクロファージで MEK-ERK が活性化し ていた. EPRAPは無刺激状態で高度にリン酸化され ていることが報告されているが, 翻訳後修飾と抗炎症 作用の関係は不明であった。そこで我々は EPRAPの 抗炎症作用に打ける翻訳後修飾の重要性を調べるため, EPRAPミュータントプラスミドを作成した，EPRAP の 108 および 608 番目のセリンをアラニンに変換し, リン酸化を受けないプラスミドをトランスフェクトし た細胞では炎症がより抑制された。また，肺胞マクロ ファージでEPRAP と脱リン酸化酵素 PP2A が結合し ていたことから，EPRAPが PP2A により 108 及び 608 番目のセリンが脱リン酸化されることで抗炎症作用を 発揮する可能性が考えられた。これらの部位が慢性炎 症疾患の治療ターゲットとなる可能性がある.

\section{EPRAP はミクログリアで资症を促進する}

ミクログリアは中枢に常在するマクロファージとも 呼ばれ，脳で炎症応答を担う細胞である，脳内炎症は 神経変性疾患の病態進行に寄与していることから，ミ クログリアがこれらの疾患の治療ターゲットとなる可 能性があり，ミクログリアの活性化メカニズムの解明 が望まれている。我々は, EPRAPが脳で大脳皮質や 海馬など様々な部位に発現し, 特にミクログリアとア ストロサイトに発現していることを明らかにした(5). LPS 腹腔内投与実験及びカイニン酸脳室内投与実験の

キーワード : EPRAP, マクロファージ，ミクログリア

京都大学大学院 医学研究科 臨床創成医学分野（７606-8501 京都市左京区吉田近衛町)

E-mail: fujirisa@kuhp.kyoto-u.ac.jp 原稿受理日：2017 年 5 月 8 日

Title: EPRAP: a key regulator of inflammation

Author: Risako Fujikawa, Sei Higuchi, Masato Nakatsuji, Mika Yasui, Masayuki Yokode, Manabu Minami 
結果，EPRAP 欠損マウスでミクログリアの活性化が 抑制されていた。初代培養ミクログリア細胞を用いた 検討により，EPRAPはマクロファージとは逆に炎症 促進に働き, MAPK 経路の 1 つ, MKK4-JNK 経路を介 していることが分かった. EP4アゴニストは野生型 及び EPRAP 欠損ミクログリアで同様に抗炎症作用を 示したことから，ミクログリアの EPRAPは EP4 シグ ナルと関連していない可能性が高い. マクロファージ とミクログリアでEPRAP の機能が異なる原因は明ら かにできていないが, EP4 受容体関連タンパク質の発 現の違いが原因の一つであると考えている。 マクロ ファージとミクログリアは遺伝子発現に相同性の高い 部分が多いものの, それぞれ特異的に発現している遺 伝子も存在する (6). EPRAP は分子内にアンキリンリ ピートと呼ばれる分子間相互作用に関わる配列を持っ ており, EP4 受容体以外のタンパク質と相互作用し, ミクログリア特異的機能に影響している可能性もある。

\section{4. 今後の可能性}

EPRAPは, 末梢のマクロファージでは MEK-ERK経 路の抑制による炎症抑制作用, 中枢のミクログリアで は MKK4-JNK 経路の促進による炎症促進作用を示し, マクロファージとミクログリアで相反する作用を持つ ことが明らかになった（図 1).ささらなる EPRAPの機 能解析や結合タンパク質の解明が，炎症が関わる疾患 の病態解明, 新たな治療法開発に繋がるであろう。

さらにEPRAP は炎症以外にも関わる多機能な分子 である可能性もある. EPRAP 欠損マウスの行動解析 を行った結果, プレパルスインヒビションの低下やう

\section{EPRAPの作用}
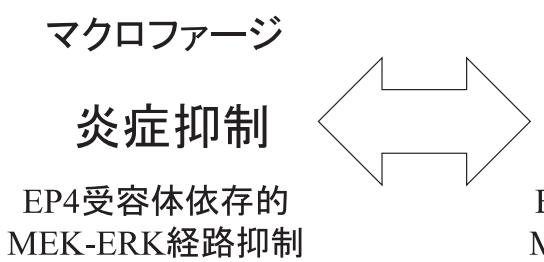

ミクログリア

炎症促進

EP4受容体非依存的 MKK4-JNK経路促進

図 1 炎症に対する EPRAP の作用

マクロファージの EPRAP は EP4 受容体依存的に MEK-ERK 経路を介 して炎症抑制に作用するのに対し，ミクログリアの EPRAP は EP4 受 容体非依存的であり, MKK4-JNK 経路を介して炎症促進に働く.

つ様行動の若干の増加など, 精神疾患様の行動異常を 示すことを明らかになった(7)。これらの異常は神経 伝達物質モノアミンの異常との関連が報告されている ため, 脳内モノアミン定量を測定したところ， EPRAP 欠損マウスでは海馬や前頭前野でノルアドレナリン量 が少ないことが分かった．神経伝達物質を調節するア ストロサイトの EPRAPがこれらの精神異常に関与し ている可能性があると考え, 今後も機能解析を進めて いく.

著者の利益相反：開示すべき利益相反はない.

$$
\text { 文献 }
$$

1) Takayama K, et al. Circ Res. 2006;98:499-504.

2) Minami M, et al. J Biol Chem. 2008;283:9692-9703.

3) Nakatsuji M, et al. PLoS Genet. 2015;11:e1005542.

4) Higuchi S, et al. J Immunol. 2016;197:4436-4443.

5) Fujikawa R, et al. Am J Pathol. 2016;186:1982-1988.

6) Hickman SE, et al. Nat Neurosci. 2013;16:1896-1905.

7) Fujikawa R, et al. Biochem Biophys Res Commun. 2017;486:584588. 